\title{
Pengembangan Pembelajaran Mastery Learning Pada Mata Kuliah Statistika Pendidikan
}

\author{
Aeng Muhidin ${ }^{1}$, Saiful Anwar ${ }^{2}$, Ubaif Al Faruq ${ }^{3}$, Shinta Doriza ${ }^{4}$
}

\section{Info Artikel}

Sejarah Artikel:

Diterima: 14 Januari 2019

Direvisi: 10 Maret 2019

Dipublikasikan: April 2019

e-ISSN: 2620-3081

p-ISSN: 1411-2744

DOI: https://doi.org/10.2100 9/JTP2001.6
Abstract: Manual pembelajaran mastery learning pada mata kuliah Statistika Pendidikan yang dikembangkan diterima oleh pengguna (3.31), dalam kategori baik dari sisi materi (3.5) dan sangat baik pada sisi media (3.9). Dari ujicoba lapangan, komponen pelaksanaan pembelajaran telah memenuhi semua komponen (10), mampu mendrong perubahan kesadaran belajar mahasiswa (3.07 ke 3.875) dan kinerja akademik (26.88\% ke 30.28). Uji beda skor tes formatif di antara dua periode siklus tindakan, menunjukkan bahwa hasil belajar statistik tidak menunjukkan perbedaan. Uji efektifitas dengan melaksanakan eksperimen diperoleh hasil bahwa rata-rata hasil tes kinerja untuk kelas eksperimen adalah 75.179 dengan varian 34.23 dan rata-rata hasil tes kinerja untuk kelas kontrol adalah 62.58 dengan varian 66.45 , pada taraf signifikansi 0.05 , diperoleh thitung (6.754) > ttabel (2.00), menunjukkan bahwa pembelajaran mastery learning dikatakan efektif digunakan dibandingkan sekedar simulasi.

Keywords: Mastery Learning, Education Statistics, Development, Learning Manuals, Learning Awareness

Abstrak: Manual pembelajaran mastery learning pada mata kuliah Statistika Pendidikan yang dikembangkan diterima oleh pengguna (3.31), dalam kategori baik dari sisi materi (3.5) dan sangat baik pada sisi media (3.9). Dari ujicoba lapangan, komponen pelaksanaan pembelajaran telah memenuhi seтua komponen (10), mampu mendrong perubahan kesadaran belajar mahasiswa (3.07 ke 3.875) dan kinerja akademik (26.88\% ke 30.28). Uji beda skor tes formatif di antara dua periode siklus tindakan, menunjukkan bahwa hasil belajar statistik tidak menunjukkan perbedaan. Uji efektifitas dengan melaksanakan eksperimen diperoleh hasil bahwa rata-rata hasil tes kinerja untuk kelas eksperimen adalah 75.179 dengan varian 34.23 dan rata-rata hasil tes kinerja untuk kelas kontrol adalah 62.58 dengan varian 66.45 , pada taraf signifikansi 0.05 , diperoleh thitung (6.754) > ttabel (2.00), menunjukkan bahwa pembelajaran mastery learning dikatakan efektif digunakan dibandingkan sekedar simulasi.

Kata kunci: Mastery Learning, Statistika Pendidikan, Pengembangan, Manual Pembelajaran, Kesadaran Belajar

\footnotetext{
${ }^{1}$ Dosen, Universitas Pamulang, aengmuhidin@unpam.ac.id

2 Dosen, Universitas Pamulang, dosen00990@unpam.ac.id

${ }^{3}$ Dosen, Universitas Pamulang, ubaidalfaruq0@ unpam.ac.id

${ }^{4}$ Dosen, Universitas Negeri Jakarta, shintadoriza@unj.ac.id
} 


\section{PENDAHULUAN}

Pembelajaran Statistika Pendidikan di Program Studi S1 Pendidikan Pancasila dan Kewarganegaraan Universitas Pamulang diorientasikan pada kemampuan menerapkan prosedur dan teknik analisis statistik sesuai dengan masalah dan jenis penelitian. Mata kuliah ini sebagai mata kuliah keahlian dan juga pelengkap untuk Mata Kuliah Metode Penelitian, diberikan untuk membekali mahasiswa dengan keahlian yang berguna untuk penyelesaian tugas akhir (skripsi). Sekitar 97\% mahasiswa Program Studi S1 PPKn menggunakan pendekatan kuantitatif yang menuntut penguasaan analisis statistik.

Dari tahun 2014 sampai tahun 2016, jumlah mahasiswa yang memperoleh nilai prasyarat minimal B, mengalami peningkatan sebesar 3.33\% dan 16.67\% secara berurutan dari 2014-2015 dan 2015-2016. Di tahun 2014, dari 30 mahasiswa, hanya 20 mahasiswa (67.67\%) yang memperoleh nilai di atas minimal nilai prasayarat B. Di tahun 2015, dari 31 mahasiswa, hanya 21 (16.67\%) yang memperoleh nilai di atas minimal nilai prasyarat B. Di tahun 2016, dari 32 mahasiswa, hanya 26 mahasiswa (81.25\%) yang memperoleh nilai di atas minimal B. Sementara itu, dalam Rapat Evaluasi Semester Ganjil 2016, dosen pengampu Mata Kuliah Statistika Pendidikan, mengungkapkan bahwa kelemahan mahasiswa Program Studi S1 PPKn, yang dianggap berpengaruh besar pada kelancaran belajar serta penguasaan materi statistika pendidikan, yaitu kemampuan matematika dasar dan penggunaan Microsoft Excel. Dosen pengampu menyampaikan mahsiswa Program Studi S1 PPKn belum menguasai dua keahlian tersebut, sehingga banyak mahasiswa mengalami kesulitan selama pembelajaran statistik berlangsung.

Rendahnya tingkat penguasaan kemampuan penerapan analisis statistik, berdampak pada perolehan nilai ujian skripsi. Dari tahun 2014 sampai 2016, dari 30 mahasiswa, 25 diantaranya menggunakan pendekatan kuantitatif. Dari 25 mahasiwa, hanya 12 mahasiswa yang memperolah nilai optimal (bobot 40), pada item Penguasaan Metodologi Penelitian. Hal itu menunjukkan bahwa pembelajaran Statistika Pendidikan belum menunjukkan hasil yang positif yakni mahasiswa mampu memilih dan menghitung jenis jenis analisis yang sesuai dengan jenis data serta mampu menyelesaikan perhitungan uji statistik sesuai dengan jenis masalah penelitian.

Kesulitan yang dialami oleh mahasiswa memang cukup beralasan. Dipandang dari segi struktur, materi mata kuliah Statistika Pendidikan, termasuk kategori materi yang rumit. Terdapat begitu banyak jenis uji statistik yang harus dipilih berdasarkan pada jenis data, jenis variabel, dan jenis masalah penelitian. Tanpa penguasaan ketiga materi tersebut, kemungkinan besar mahasiswa mengalami kesulitan dalam analisis statistik. Jika dilihat dari latar belakang karakteristik mahasiswa Program Studi S1 PPkn, dari 1.000 mahasiswa, 70\% merupakan lulusan SMK, 20\% lulusan SMA, dan 10\% lulusan

paket $\mathrm{C}$, menjadi rasional jika penguasaan komponen keahlian berupa kemampuan dasar penguasaan operasi matematika begitu lemah. Pembelajaran penguasaan komponen keterampilan berupa operasi matematka dasar menjadi suatu kebutuhan untuk penguasaan analisis statistik. Selain itu, materi analisis statistik bersifat hierarkis. Dalam analisis statistik, pemilihan jenis uji sangat tergantung pada hasil uji persyaratan analisis (normalitas dan homogenits), sehingga kemungkinan peneliti dapat memilih 
analisis parametrik atau non-parametrik. Tanpa penguasaan materi yang lebih awal seperti penguasaan teknik uji persyaratan analisis, pembelajaran untuk materi tingkat lanjut seperti uji parametrik dan atau non-parametrik, akan terganggu.

Dalam menghadapi fenomena belajar itu, perlu ada usaha kreatif dari dosen untuk memfasilitasi kesulitan belajar yang dihadapi mahasiswa. Sementara itu, peneliti lain menyarankan pembelajaran yang mendorong pada penguasaan (mastery learning), selanjutnya disingkat ML), dapat mengantarkan mahasiswa pada penguasaan capaian pembelajaran yang diharapkan. Untuk mendorong ML, pembelajaran harus dikondisikan pada aktivitas belajar penguasaan beberapa komponen keahlian melalui pemberian latihan terstruktur yang cukup dan umpan balik. Penguasaan komponen keahlian sangat penting, sebagaimana dibuktikan oleh Kordinger dan Anderson, ketika mahasiswa sudah menguasai komponen keahlian, kemampuan mahasiswa akan mengalami peningkatan secara signifikan (Anderson \& Jones, 1981).

Menurut Molenda, Reigeluth and Nelson (2003), desain pembelajaran (instructional design) mengacu pada prinsip dan prosedur yang dijalankan dalam mengembangkan materi bahan ajar, pengjaran, dan sistem pembelajaran secara keseluruhan dengan cara yang konsisten dan dapat dipercaya (Richey \& Klein, 2005a). Ritchey, Klein and Tracey menyatakan bahwa desain pembelajarana dalah ilmu dan seni untuk pengembangan, evaluasi dan pengendalian situasi pembelajaran secara spesifik dalam rangka memfasilitasi pembelajaran dan performa akademik (Richey \& Klein, 2005b). Menurut Smith dan Ragan, desain pembelajaran adalah proses sistematis dan reflektif dalam menterjemahkan prinsip belajar dan pengajaran ke dalam rencana materi bahan ajar, aktivitas, sumber belajar dan evaluasi (Patricia L. Smith dan Ragan 2005, 85).

Kerangka desain pembelajaran ADDIE terdiri dari lima tahap: (1) Analisis situasi pembelajaran; (2) Merancang tujuan dan sasaran belajar yang sesuai dengan situasi belajar; (3) Mengembangkan sumber belajar yang cocok dengan sasaran yang bersifat spesifik; (4) Melaksanakan rancangan pada situasi belajar yang dihadapi, dan (5) evaluasi bagaimana pelaksanaan pembelajaran telah mengatasi situasi belajar yang dihadapi (Molenda, 2015). Molenda sendiri menyatakan bahwa ADDIE adalah pendekatan berbasis proses dalam mengembangkan kegiatan pembelajaran. Dalam penelitian ini, penggunaan ADDIE digunakan dalam merancang kegiatan pembelajaran ML. Mengingat pembelajaran penguasaan merupakan suatu model pembelajaran, maka penggunaan model ADDIE, maka siklus pembelajaran penguasaan (lihat Gambar 1) terintegrasi dengan A-D-D-I-E.

Pembelajaran penguasaan (mastery learning, selanjutnya disebut ML) dikembangkan sebagai cara dosen memberikan pengajaran yang berkualitas dan lebih tepat bagi mahasiswa mereka. Swelller mengungkapkan bahwa pembelajaran yang mendorong penguasaan komponen keahlian melalui latihan terpisah dari konteks keseluruhan, sangat membantu mahasiswa, terutama pemula dan belum mahir (Clark, Kirschner, \& Sweller, 2012). ML sangat kontraproduktif jika diberikan pada mahasiswa yang sudah mahir (Clark et al., 2012). Pembelajaran penguasaan statistika pendidikan menuntut penguasaan 
penguasan pengetahuan sebelumnya (prior knowledges) yang dipersyaratkan harus dimiliki sebelum penguasaan analisis statistik.

Pembelajaran penguasaan tidak hanya dipengaruhi oleh faktor pengetahuan mahasiswa sebelumnya. Guskey mengatakan bahwa keberhasilan pembelajaran penguasaan dipengaruhi oleh dua faktor waktu, yaitu waktu yang dihabiskan dan waktu yang dibutuhkan (Gusket, 2007). Waktu yang dihabiskan ditentukan oleh kesempatan (opportunity) dan ketekunan (preserve) mahasiswa dalam belajar. Sedangkan waktu yang dibutuhkan, ditentukan oleh tingkat belajar, kualitas pembelajaran, dan kemampuan untuk memahami pembelajaran. Penyebab rendahnya penguasaan materi statistika pendidikan dan rendahnya nilai hasil belajar, kemungkinan besar kekurangan waktu belajar dan berlatih penguasaan komponen keterampilan.

Hal lain yang juga penting diperhatikan dalam pembelajaran penguasaan yaitu desain dan struktur materi perkuliahan. Elemen-elemen pembelajaran penguasaan seperti penguasaan pengetahuan terdahulu, penguasaan komponen keahlian melalui latihan, pembagian materi kompleks ke materi yang lebih sederhana, merupakan elemen dasar dalam pembelajaran penguasaan (mastery learning) ( $\mathrm{T}$. R. Guskey, 2001). Desain pembelajaran penguasaan keterampilan analisis statistik harus fokus diarahkan pada proses pemberian latihan dan umpan balik secara yang dirancang secara bertahap dan sistematis untuk meningkatkan efektivitas belajar.

ML mengharuskan mahasiswa menunjukkan pemahaman mendalam tentang topik kuliah tertentu sebelum melanjutkan ke topik berikutnya. Dari pengalaman penerapan ML, Carrol mengusulkan agar dosen lebih fokus pada waktu. Menurutnya, jika setiap mahasiswa menghabiskan waktu dengan tepat, kemungkinan mereka akan mencapai prestasi yang diharapkan (Carroll, Smith-Kerker, Ford, \& MazurRimetz, 1987). Waktu yang dihabiskan ditentukan oleh ketekunan dan kesempatan untuk belajar. Jika mahssiwa tekun dan diberikan kesempatan untuk berlatih, maka waktu yang digunakan akan lebih banyak dibandingkan ketika kriteria yang dimaksud tidak nampak. Waktu yang dibutuhkan ditentukan oleh tingkat belajar pada subjek materi, kualitas pengajaran, dan kemampuan anak untuk memahami materi. Jika kualitas pengajarannya sangat tinggi, akan mudah bagi mahasiswa memahami materi dan mungkin perlu sedikit waktu untuk belajar. Namun, jika kualitas instruksinya tidak tinggi, maka mahasiswa akan mengalami kesulitan lebih besar, dan akan membutuhkan lebih banyak waktu untuk belajar. Dengan kata lain, kualitas instruksi dan kemampuan anak untuk memahami instruksi berinteraksi dengan jumlah waktu yang dibutuhkan anak untuk mempelajari konsep atau materi.

Penerapan ML dilakukan per unit pembelajaran ML terdiri dari lima komponen inti: preassessment, instruksi, penilaian formatif, koreksi/pengayaan, dan penilaian sumatif (T. R. Guskey, 1980a). Kelima aspek tersebut bersifat linear, dilaksanakan secara berurutan.

Pra-penilaian (Pre-assessment) adalah instrumen atau metode yang digunakan dosen untuk menentukan pengetahuan, keterampilan, atau sikap mahasiswa sebelum melaksanakan pengajaran. Prapenilaian adalah cara untuk mengumpulkan bukti kesiapan siswa, minat, atau profil belajar sebelum memulai pelajaran atau unit dan kemudian menggunakan bukti itu untuk merencanakan pembelajaran 
yang akan memenuhi kebutuhan belajar (T. Guskey \& McTighe, 2016). Sering juga disebut dengan tes diagnostik yang ingin mengukur pengetahuan dan keterampilan yang dibutuhkan di setiap pertemuan.

Sebelum dimulainya unit, dilakukan pra-penilaian untuk mengidentifikasi apakah mahasiswa memiliki pengetahuan dasar dan keterampilan yang diperlukan untuk sukses dalam unit yang akan datang/yang akan dipelajari. Jika mahasiswa tidak memiliki pengetahuan prasyarat yang diperlukan, segera diberikan remediasi untuk mahasiswa tersebut.

Mengingat pra-penilaian sebagai suatu kegiatan untuk mengukur kemampuan awal mahasiswa sebelum pembelajaran dimulai, maka produk yang dikembangkan adalah instrumen penilaian. Instrumen yang digunakan pada pra-penilaian adalah pre-test dan kuesioner. Jenis penilaian pada penilaian awal adalah pilihan ganda (multiple choice) digunakan untuk mengetahui pengetahuan dan keterampilan sebelumnya. Kuesioner digunakan untuk mengkonfirmasi pengetahuan tentang konsepkonsep yang akan dipelajari. Untuk mendorong minat mahasiswa dan menghidupkan suasana belajar yang menyenangkan, pre-test dan kuesioner akan menggunakan alat penilaian berbasis web yaitu kahoot.it.

Jika mereka mampu melakukannya dengan baik, komponen kedua adalah pembelajaran pada konten unit. Pembelajaran adalah kegiatan belajar, sebagai aktivitas yang dilakukan mahasiswa dalam mempelajari materi mata kuliah. Materi mata kuliah yang dipelajari merujuk pada kata kerja dan kriteria dalam rumusan capaian pembelajaran pokok bahasan (CPBB). CPBB ini sebagai jabaran rinci dari rumusan capaian pembelajaran mata kuliah (CPMK).

Dalam pembelajara ML, dosen harus dapat memberikan latihan dan umpan balik yang spesifik tentang kemajuan belajar secara reguler, melalui penilaian formatif. Penilaian formatif bersifat diagnostik dan preskriptif (saran) untuk memastikan apa yang diharapkan mahasiswa untuk dipelajari, mengidentifikasi apa yang mereka pelajari dengan baik, dan menjelaskan apa yang perlu dipelajari lebih baik. Perbaikan yang signifikan memerlukan umpan balik dan harus dipadankan dengan koreksi, bimbingan dan arahan tentang bagaimana memperbaiki masalah belajar mereka (T. R. Guskey, 1997, hal. 36). Karena adanya perbedaan individu di antara mahasiswa, tidak ada metode instruksi tunggal yang paling sesuai untuk semua orang. Untuk membantu setiap mahasiswa belajar dengan baik, pengajaran yang berbeda pada setiap individu sangat diperlukan, terutama sekali melalui kegiatan perbaikan. Agar efektif, koreksi harus berbeda secara kualitatif dari pengajaran awal. Juga harus menawarkan pendekatan alternatif dan waktu tambahan agar mahasiswa dapat belajar lebih baik.

Penilaian formatif diikuti dengan pelaksanaan komponen keempat, dosen memberikan instruksi korektif singkat (misalnya, satu atau dua hari) untuk memperkuat dan memperbaiki kelemahan mahasiswa sebagaimana informasi yang diperoleh dari hasil penilaian formatif. Dalam kondisi lain, kegiataan pengayaan juga diberikan meski mahasiswa mampu menunjukkan penguasaan. Mahasiswa dapat menerima kegiatan pengayaan yang menawarkan pengalaman belajar yang lebih menantang di luar tingkat penguasaan. Pembelajaran pada tahap koreksi atau pengayaan biasanya dilakukan dalam kelompok kecil atau individual. 


\section{METODE}

Penelitian ini bertujuan untuk menghasilkan model pembelajaran mastery learning (ML) pada mata kuliah Statistika Pendidikan. Produk yang ingin dikembangkan adalah desain pembelajaran mastery leraning (ML) sebagai panduan bagi dosen dalam melaksanakan pembelajaran di Mata Kuliah Statistika Pendidikan. Penelitian ini menggunakan pendekatan gabungan dengan menggunakan model A-D-D-I-E. Model ADDIE terdiri dari lima langkah, yaitu Analysis (A), Design (D), Development (D), Implementation (I) dan Evaluation (E), yang bersifat siklis.

Pada tahap analisis, diketahui bahwa pembelajaran statistika pendidikan yang diperlukan adalah simulasi perhitungan Excel dengan urutan tahapan pembelajaran yang terperinci, dengan umpan balik yang maksimal, karena itu dibutuhkan pendekatan pembelajaran mastery learning dalam pelaksanaan pembelajaran. Untuk itu, perlu dibuat produk berupa manual pembelajaran mastery learning.

Pada tahap awal, sebelum dikembangkan lebih lanjut, rancangan manual divalidasi oleh ahli materi dan ahli materi. Selanjutnya dilakukan ujicoba kelompok kecil untuk mengetahui daya penerimaan pengguna terhadap produk. Selanjutnya dilakukan validasi oleh satu orang ahli media dan satu orang ahli materi, untuk mengetahui tingkat kesesuaian. Ujicoba dilakukan dalam skema penelitian tindakan kelas, yang dirancang selama 2 siklus. Tes keefektifan produk dilakukan dalam skema penelitian eksperimen, pada dua kelas, kelas eksperimen yang diperlakukan dengan pendekatan mastery learning dan kelas kontrol yang diperlakukan dengan metode simulasi tanpa mengintegrasikan elemen mastery learning.

\section{HASIL PENELITIAN}

Manual pembelajaran yang dikembangkan dinilai oleh ahli materi dan ahli media. Validasi pakar materi dilakukan untuk mengetahui empat aspek, yaitu ketepatan rumusan capaian pembelajaran, ketepatan materi yang dipelajari, ketepatan pemilihan uji statistik, dan ketepatan penulisan rumus dan simbol, diperoleh rata-rata sebesar 3.5. Validasi pakar media dilakukan untuk mengetahui aspek desain tata letak dan aspek prinsip pembelajaran ML. Hasil validasi ahli media diperoleh rata-rata penilaian sebesar 3.96 .

Uji kelayakan dilakukan mengetahui tanggapan penerimaan pengguna (user acceptance using) pada lima dimensi, diperoleh hasil yaitu: kompatibilitas (rata-rata=3.31), manfaat (3.35), persepsi kemudahan menggunakan (rata-rata=3.25), persepsi kualitas yang dirasakan (rata-rata=3.34), efikasi diri (rata-rata=3.23), dan niat menggunakan (rata-rata=3.42), dengan rata-rata total sebesar 3.31, menunjukkan bahwa produk layak diujicobakan.

Ujicoba dilaksanakan dalam bentuk penelitain tindakan selama 2 siklus tindakan. Selama percobaan, dilakukan pengukuran kesadaran belajar dan kinerja akademik. Dari siklus 1 ke siklus kedua, nampak bahwa kesadaran belajar mahasiswa mengalami perubahan, dari 3.07 ke 3.87. Perubahan itu terjadi, setelah dosen memberikan tekanan pada setiap tahap pembelajaran. Perubahan tindakan yang dilakukan oleh dosen pengampu menunjukkan bahwa perubahan kesadaran belajar terjadi ketika 
intervensi dilakukan lebih dalam. Hasil uji-t pada taraf signifikansi $(\alpha=0.05)$, diketahui thitung $=0.155$ $<$ ttabel $=2.002$, menunjukkan bahwa tidak ada perbedaan rata-rata hasil belajar mahasiswa antara ujicoba pertama dan ujicoba kedua. Ketiadaan perbedaan tersebut menunjukkan pembelajaran mastery learning pada kedua kelompok sama-sama dapat meningkatkan kesadaran belajar.

Pengukuran kinerja akademik dilakukan per siklus tindakan, untuk mengamati pergerakan nilai dari tes diagnostik ke tes formatif, dan tes sumatif, menunjukkan bahwa kemajuan belajar mahasiswa dari siklus tindakan 1 ke siklus tindakan 2 mengalami pergeseran, dari 30.28 ke 26.88. Hasil uji beda (Uji-t) pada taraf signifikansi $(\alpha=0.05)$, diketahui thitung $=-0.75<$ ttabel $=2.002$, berarti Ho diterima, menunjukkan bahwa tidak ada perbedaan rata-rata hasil belajar mahasiswa antara ujicoba pertama dan ujicoba kedua. Ketiadaan perbedaan tersebut berarti pembelajaran mastery learning pada kedua kelompok waktu sama-sama dapat meningkatkan kesadaran belajar.

Selanjutnya, untuk menguji efektifitas model pembelajaran mastery learning, pengembang melakukan eksperimen. Desain eksperimen menggunakan desain kuasi eksperimen, yang membandingkan dua kelompok yang diperlakukan berbeda. Kelas 05PPKM003 diperlakukan dengan pembelajaran mastery learning (Eksperimen) dan kelas 05PPKP002 diperlakukan dengan pembelajaran simulasi (Kelas Kontrol). Rata-rata hasil tes kinerja untuk kelas eksperimen adalah 75.179 dengan varian 34.23. Rata-rata hasil tes kinerja untuk kelas kontrol adalah 62.58 dengan varian 66.45. Hasil uji statisitk pada taraf signifikansi 0.05, diperoleh thitung (6.754) > ttabel (2.00), dan Ho ditolak. Pengujian statistik membuktikan bahwa terdapat perbedaan hasil belajar mahasiswa yang diperlakukan dengan pembelajaran mastery learning dengan hasil belajar mahasiswa yang diperlakukan dengan metode simulasi biasa.

\section{PEMBAHASAN}

Hasil eksperimen menunjukkan bahwa mahasiswa yang diperlakukan dengan pendekatan mastery learning (ML) dapat belajar lebih baik dalam mempelajari keterampilan statistik. Peneliti tidak terkejut dengan hasil ini karena kesuksesan pembelajaran ML dalam banyak disiplin telah banyak dilaporkan (Belenky \& Nokes-Malach, 2013; Davrajoo, Tarmizi, Nawawi, \& Hassan, 2010; Gray, Chang, \& Anderman, 2015; T. R. Guskey, 1980b; Hockett \& Doubet, 2014; Mevarech \& Susak, 1993; Schiefele \& Schaffner, 2015; Shafie, Shahdan, \& Liew, 2010)

Penelitian ini mendukung temuan penelitian Belenky dan Nokes-Malach (2013) yang menyatakan bahwa mahasiswa yang belajar dengan berorietasi pada penguasaan dapat menyelesaikan soal pada post-tes matematika. Hanya saja, penelitian yang dilakukan oleh Belenky dan Nokes-Malach (2013) tidak dapat mendokumentasikan perubahan kesadaran belajar terjadi. Dalam situasi eksperimen memang tidak dapat ditunjukkan. Dari penelitian ini menunjukkan perubahan kesadaran belajar mahasiswa dari ujicoba pertama ke ujicoba kedua. Kesadaran belajar mahasiswa yang diukur dengan instrumen 12 item, mengalami peningkatan dari ujicoba pertama $(x=3.0)$ ke ujicoba kedua $(x=3.5)$. 
Perubahan kesadaran tersebut memang tidak dapat dengan sendirinya. Dalam refleksi ujicoba yang pertama, peneliti dan kontributor (dosen pengampu) menekankan pentingnya mengingatkan proses belajar dari satu tahap ke tahap berikutnya, dari tahap tes diagnostik ke tahap uji formatif dan remedial. Hasil penelitian ini menunjukkan bahwa pembelajaran mastery learning bukan sekedar menata pembelajaran dari bongkahan besar ke bongkahan kecil, tetapi perlu juga memberikan kesempaptan kepada mahasiswa untuk refleksi atas proses pembelajaran (Muhidin, 2017, hal. 147). Pembelajaran mastery learning dan pemberian kesempatan untuk refleksi, dapat menggerakan dari ketidaksadaran akan ketiadaan kompetensi menunju ke kesadaran akan kompetensi.

Hasil penelitian memberikan dukungan kepada gagasan bahwa pengintegrasian kooperatif learning dalam pembelajaran ML berkontribusi terhadap prestasi akademik kinerja akademik (Krank \& Moon, 2001). Hanya saja keterbatasan dalam penelitian ini, tidak dapat dipastikan apakah kinerja akademik mahasiswa karena pengaruh pembelajaran mastery learning ataukah karena pembelajaran tutor teman sebaya, mengingat dalam ujicoba dan eksperimen yang dilakukan, peneliti meminta teman sebaya yang sudah mahir mengajari temannya yang belum bisa. Tidak dapat dipungkiri bahwa tutor teman sebaya memberikan pengaruh positif terhadap kinerja akademik. Xu, et.al (2001) menunjukkan bahwa tutor teman sebaya dapat memfasilitasi pembelajaran dengan membantu mahasiswa untuk memahami dan menerapkan pengetahuan yang dipelajarinya.

Meskipun akuntabilitas kemajuan hasil belajar di antara periode belajar dalam pelaksanaan ujicoba, tidak dapat dipungkiri bahwa tidak ada strategi pembelajaran yang seakuntabel mastery learning. Penggunaan manual pembelajaran mastery learning ini didasarkan pada keinginan peneliti untuk memberikan bantuan dan memfasilitasi mahasiswa untuk menguasai kompetensi analisis statistik dengan menciptakan pembelajaran dengan struktur kompetensi yang jelas dan sistematis. Hasil penelitian ini menunjukkan bahwa mahasiswa Penelitian terdahulu menunjukkan bahwa dosen yang berorientasi pada penguasaan, akan memberikan bantuan lebih kepada mahasiswa dan dapat mendorong mahasiswa juga berorientasi pada tujuan penguasaan (Schiefele \& Schaffner, 2015). Perubahan kesadaran belajar mahasiswa dari ujicoba pertama ke ujicoba kedua menunjukkan adanya perubahan orientasi dari ketidaksadaran ketidakmampun menuju pada kesadaran kompetensi.

Hasil penelitian juga mendukung gagasan bahwa penggunaan Microsoft Excel dapat membantu dosen dalam mengajarkan perhitungan statistik dan dapat meningkatkan keterampilan komputer (Davis \& Davis, 1999; Warner \& Meehan, 2001). Mahasiswa lebih suka belajar untuk memperkuat keterampilan komputer ((Davis \& Davis, 1999). Penggunaan komputer dan perangkat lunak, termasuk Excel, telah umum digunakan dalam mengajarkan statistik. Tetapi, banyak guru statistik selalu mencari metode pengajaran baru alternatif untuk meningkatkan kompetensi statistik (Jamie, 2002), penelitian ini menunjukkan bahwa penggunaan Microsof Excel untuk mensimulasikan perhitungan data dan uji statistik dapat menigkatkan kinerja akademik mahasiswa dalam tes formatif uji statistik. 


\section{KESIMPULAN}

Berdasarkan pada hasil pengembangan manual pembelajaran mastery learning pada mata kuliah Statistika Pendidikan di Program Studi S1 Pendidikan Pancasila dan Kewarganegaran, modul dianggap telah diterima oleh pengguna (3.31). Pengembangan modul memperoleh nilai baik pada komponen materi (3.5) maupun pada komponen media (3.9). Dari hasil penilaian tersebut, manual pembelajaran mastery learning layak diimplementasikan.

Ujicoba melalui penelitian tindakan dengan target pemenuhan komponen pembelajaran mastery learning, perubahan kesadaran belajar, dan perubahan kemajuan belajar, menunjukkan hasil yang memuaskan. Dari segi komponen pelaksanaan pembelajaran telah memenuhi semua komponen (10). Dari segi perubahan keasadaran belajar, penerapan pembelajaran mastery learning dapat merubah kesadaran belajar mahasiswa dari 3.07 di siklus tindakan 1 menjadi 3.875 pada siklus kedua. Dari segi perubahan kinerja akademik, juga menunjukkan hasil yang baik. Kinerja akademik mahasiswa mengalami perubahan ke arah yang baik dengan gap kesenjangan kemampuan dari periode sebelum belajar (hasil tes diagnostik) ke periode setelah belajar (hasil tes formatif) dan ke periode akhir belajar (hasil tes formatif) mengalami pergesaran sampai ke tingkat sampai $26.88 \%$ di siklus kedua dari 30.28 di siklus pertama. Untuk menunjukkan kelayakan model, dilakukan uji beda tes formatif di antara dua periode siklus tindakan, menunjukkan bahwa hasil belajar statistik tidak menunjukkan perbedaan.

Untuk menguji efektifitas manual pembelajaran mastery learnig dilakukan eksperimen dengan desain kuasi eksperimen. Berdasarkan hasil eksperimen rata-rata hasil tes kinerja untuk kelas eksperimen adalah 75.179 dengan varian 34.23 dan rata-rata hasil tes kinerja untuk kelas kontrol adalah 62.58 dengan varian 66.45. Hasil uji statisitk pada taraf signifikansi 0.05, diperoleh thitung (6.754)> ttabel (2.00), dan Ho ditolak. Pengujian statistik membuktikan bahwa terdapat perbedaan hasil belajar mahasiswa yang diperlakukan dengan pembelajaran mastery learning dengan hasil belajar mahasiswa yang diperlakukan dengan metode simulasi biasa. Hal itu menunjukka bahwa manual pembelajaran mastery learning dikatakan efektif digunakan. Secara keseluruhan, dapat dikatakan bahwa manual pembelajaran mastery learning yang dikembangkan dengan model ADDIE melalui beragam tahapan dikatakan sebagai manual pembelajaran yang baik, layak digunakan dan efektif.

\section{DAFTAR PUSTAKA}

Anderson, L. W., \& Jones, B. F. (1981). Designing instructional strategies which facilitate learning for mastery. Educational Psychologist, 16(3), 121-138. https://doi.org/10.1080/00461528109529235

Belenky, D. M., \& Nokes-Malach, T. J. (2013). Mastery-approach goals and knowledge transfer: An investigation into the effects of task structure and framing instructions. Learning and Individual Differences, 25, 21-34. https://doi.org/10.1016/J.LINDIF.2013.02.004

Carroll, J., Smith-Kerker, P., Ford, J., \& Mazur-Rimetz, S. (1987). The Minimal Manual. HumanComputer Interaction, 3(2), 123-153. https://doi.org/10.1207/s15327051hci0302_2 
Clark, Ri. E., Kirschner, P. A., \& Sweller, J. (2012). Putting Students on the Path to Learning: The Case for Fully Guided Instruction. American Educatior, 36(1), 6-11. Diambil dari https://eric.ed.gov/?id=EJ971752

Davis, P., \& Davis, P. (1999). How Undergraduates Learn Computer Skills: Results of a Survey and Focus Group. T.H.E. Journal, 26(9), 68-71. Diambil dari https://www.learntechlib.org/p/89352/

Davrajoo, E., Tarmizi, R. A., Nawawi, M., \& Hassan, A. (2010). Enhancing Algebraic Conceptual Knowledge with Aid of Module Using Mastery Learning Approach. Procedia - Social and Behavioral Sciences, 8, 362-369. https://doi.org/10.1016/J.SBSPRO.2010.12.051

Gray, D. L., Chang, Y., \& Anderman, E. M. (2015). Conditional effects of mastery goal structure on changes in students' motivational beliefs: Need for cognition matters. Learning and Individual Differences, 40, 9-21. https://doi.org/10.1016/j.lindif.2015.03.025

Gusket, T. R. (2007). Closing Achievement Gap, Revisiting Benjamin S. Bloom Learning For Mastery. Journal of Advanced Academics, 19(1), 8-31. Diambil dari www.CutePDF.com

Guskey, T., \& McTighe, J. (2016). PRE-ASSESSMENT: Promises and Cautions. Educational Leadership. Diambil dari https://uknowledge.uky.edu/edp_facpub/17

Guskey, T. R. (1980a). Mastery learning: Applying the theory. Theory Into Practice, 19(2), 104-111. https://doi.org/10.1080/00405848009542882

Guskey, T. R. (1980b). Mastery learning: Applying the theory. Theory Into Practice, 19(2), 104-111. https://doi.org/10.1080/00405848009542882

Guskey, T. R. (1997). Implementing mastery learning. Wadsworth Pub. Co. Diambil dari https://books.google.co.id/books?id=8VZjQgAACAAJ\&dq=Implementing+Mastery+Learning\& $\mathrm{hl}=\mathrm{en} \& \mathrm{sa}=\mathrm{X} \& \mathrm{ved}=0 \mathrm{ahUKEwiA9}$ saojsLdAhVJqI8KHaTmAjsQ6AEIJzAA

Guskey, T. R. (2001). Benjamin S. Bloom's Contributions to Curriculum, Instruction, and School Learning. Diambil dari https://eric.ed.gov/?id=ED457185

Hockett, J. A., \& Doubet, K. J. (2014). Turning on the Lights: What Pre-Assessments Can Do Educational Leadership. Educational Leadership, 71(4), 50-54. Diambil dari http://www.ascd.org/publications/educational_leadership/dec13/vol71/num04/Turning_on_the_ Lights@_What_Pre-Assessments_Can_Do.aspx

Jamie, D. M. (2002). Using Computer Simulation Methods to Teach Statistics: A Review of the Literature. Journal of Statistics https://doi.org/10.1080/10691898.2002.11910548

Krank, H. M., \& Moon, C. E. (2001). Can a Combined Mastery/Cooperative Learning Environment Positively Impact Undergraduate Academic and Affective Outcomes? Journal of College Reading and Learning, 31(2), 195-207. https://doi.org/10.1080/10790195.2001.10850115

Mevarech, Z. R., \& Susak, Z. (1993). Effects of Learning with Cooperative-Mastery Method on Elementary Students. The Journal of Educational Research, 86(4), 197-205. https://doi.org/10.1080/00220671.1993.9941831

Molenda, M. (2015). In Search of the Elusive ADDIE Model. Performance Improvement, 54(2), 4042. https://doi.org/10.1002/pfi.21461

Muhidin, A. (2017). Mengajar Efektif: Pendekatan Berpusat Pada Mahasiswa. (S. Anwar \& U. Al 
Faruq, Ed.) (1 ed.). Tangerang Selatan: Unpam Press. Diambil dari www.unpam.ac.id

Richey, R. C., \& Klein, J. D. (2005a). Developmental research methods: Creating knowledge from instructional design and development practice. Journal of Computing in Higher Education, 16(2), 23-38. https://doi.org/10.1007/BF02961473

Richey, R. C., \& Klein, J. D. (2005b). Developmental research methods: Creating knowledge from instructional design and development practice. Journal of Computing in Higher Education, 16(2), 23-38. https://doi.org/10.1007/BF02961473

Schiefele, U., \& Schaffner, E. (2015). Teacher interests, mastery goals, and self-efficacy as predictors of instructional practices and student motivation. Contemporary Educational Psychology, 42, 159-171. https://doi.org/10.1016/J.CEDPSYCH.2015.06.005

Shafie, N., Shahdan, T. N. T., \& Liew, M. S. (2010). Mastery Learning Assessment Model (MLAM) in Teaching and Learning Mathematics. Procedia - Social and Behavioral Sciences, 8, 294-298. https://doi.org/10.1016/J.SBSPRO.2010.12.040

Smith, P. L. (Patricia L., \& Ragan, T. J. (2005). Instructional design. J. Wiley \& Sons.

Warner, C. B., \& Meehan, A. M. (2001). Microsoft Excel ${ }^{\mathrm{TM}}$ as a Tool for Teaching Basic Statistics. Teaching of Psychology, 28(4), 295-298. https://doi.org/10.1207/S15328023TOP2804_11

Xu, Y., Hartman, S., Uribe, G., \& Mencke, R. (2001). The Effects of Peer Tutoring on Undergraduate Students' Final Examination Scores in Mathematics. Journal of College Reading and Learning, 32(1), 22-31. https://doi.org/10.1080/10790195.2001.10850123. 